\title{
The Consequence of Credit Performance and Capital Adequacy: Evidence from Commercial Banks in Nepal
}

Bijay Gopal Shrestha, M.Phil.

Professor, Tribhuvan University

Email: bigostha@gmail.com

Damodar Niraula, M.Phil.

Faculty, Nesfield International College

Email: damodarniraula@gmail.com

\begin{abstract}
Following random effect GLS model, this study aims at examining the consequence of credit performance and capital adequacy of Nepalese commercial banks. For the analysis, the balanced panel data of 19 commercial banks have judgmentally been selected and used. The researcher took credit to deposit ratio (CDR), interest rate spread (IRS), non-performing loan ratio (NPLR) and capital adequacy ratio (CAR) as the predictors of profitability measured by return on assets (ROA) of the banks. The results indicate that the study predictors are significant in defining variation on ROA. The variables CDR and NPLR have significant negative impact on ROA. In contrast, the predictors IRS and CAR have positive consequence on ROA. However, the relationship between CAR and ROA is statistically insignificant. Results of the study can contribute as an important input to regulatory body in developing policy so as to make banking operation effective.
\end{abstract}

Keywords: credit performance, capital adequacy, Nepalese commercial banks, nonperforming loan, return on assets

\section{Introduction}

Credit performance and strong capital base along with the managerial efficiency are considered as major indicators of healthy banks and other financial institutions. Credit performance involves the act of financial intermediation of the bankers that collect money from the surplus sector in the form of deposits and lend it to diverse sectors of the economy. Capital adequacy, on the other hand, is the statutory minimum amount of capital reserve that a financial institution must have available. It is regarded as an important indicator of bank stability (Mohanty \& Mahakud, 2019), sustainability (Bhattarai, 2020), and is indispensable to prevent bankruptcy of banks and to protect depositors' funds. 
As credit performance and capital adequacy are the crucial to bank profitability, they are subject to critical analysis and assessment regarding their effect on profitability performance of banks. For one, Pradhan and Shrestha's study (2016), a causal comparative study of 17 commercial banks of Nepal, identified loan rate and capital adequacy ratio (CAR) were the significant determinants of bank performance, and concluded that CAR had negative impact on return on assets (ROA). However, Neupane (2020) also confirmed insignificant negative influence of CAR on ROA. And, Budhathoki and Rai (2020) argued that the higher CAR decreases ROA of banks as a consequence of reduced bank risk. In contrast, some previous studies (e.g., Gnawali, 2018; Gautam, 2018; Risal \& Poudel, 2020) revealed a positive relationship of ROA with CAR. In terms of return on equity (ROE) as well, Poudel (2018) found a significant positive effect of CAR. However, Bhattarai (2016) reported that CAR was not a significant variable influencing bank performance.

Ranabhat (2019) conducted a study to examine the impact of bank specific variables on financial performance of joint venture banks in Nepal. The researcher used ROA and $\mathrm{ROE}$ as the measures of financial performance. Result of Pooled OLS multiple regression model revealed that both the spread rate and CAR had significant positive effect on performance of the banks. Bhatia, Mahajan, and Chander (2012) had also found significant positive relation between interest rate spread (IRS) and ROA. However, the finding of Poudel (2018) was quite different, he found insignificant negative impact of spread rate on profitability.

Using one-step generalized methods of moments (GMM) estimator, Islam and Nishiyama (2016) studied the determinants of profitability of South Asian banks. Profitability of the banks is measured in term of ROA. Analysis of cross-country panel data for the period 1997-2012 of 259 commercial banks of Bangladesh, India, Nepal and Pakistan found that the non-performing loan ratio (NPLR) had insignificant negative relation with ROA. But Bhatia, Mahajan, and Chander (2012), Bhattarai (2016), and Poudel (2018), found significant negative relation of NPLR with ROA. Similarly, findings are not uniform in terms of relation between credit to deposit ratio (CDR) and ROA. For example, Islam and Nishiyama (2016) found significant negative impact of CDR on profitability. However, the study of Gnawali (2018) and Risal and Poudel (2020) revealed positive relationship between CDR and ROA. Based on the empirical evidences, it can be concluded that there is inconsistency in the findings of study conducted by different researchers at different time and context. Therefore, this research aims at establishing the relationship of credit performance and capital adequacy on profitability of commercial banks in Nepal. 


\section{Research Methodology}

This study deploys secondary data collected from the annual reports of private sector commercial banks licensed by Nepal Rastra Bank. Based on the judgmental sampling, nineteen banks have been selected as a sample to collect data from the fiscal year $2015 / 016$ to $2019 / 020$ for each. Hence, the study is based on the balanced panel data containing the number of observations ninety-five in total. The rationale behind the judgmental sampling is to assure the heterogeneity in the sample in terms of age, size, and ownership structure.

The research design for this study is causal comparative in nature as it deals with the consequence of credit performance and capital adequacy. Specifically, the study assesses the consequence of credit deposit ratio, interest rate spread, non-performing loan ratio, and capital adequacy ratio on the return on assets of the commercial banks in Nepal.

\section{The Model}

As indicated by Gujarati, Porter, and Gunasekar (2012), Ordinary Least Squares (OLS) used extensively in regression analysis primarily because it is intuitively appealing and mathematically much simpler than the other. Accordingly, to confirm suitable model through the panel diagnostic, at the beginning, the Pooled OLS model has been estimated in the study. In the process, primarily, Model 1 has been used.

$$
Y_{i t} \quad=\alpha+\beta^{\prime} X_{i t}+\varepsilon_{i t} \quad(\text { Model 1) }
$$

Where, $Y$ represents a dependent variable; $\alpha$ is constant; $\beta$ ' is the coefficient of explanatory variables; $X_{i t}$ is the vector of explanatory variables; and $\varepsilon_{i t}$ is the error term. By using the model diagnostic, it has been confirmed the random effect model as an appropriate one (see Table 2). Thus, with the confirmation through the model diagnostic, this study had attempted to draw the inferences by using Model 2, random-effect general least squares (GLS) model. The random effects model decomposes the residual variance into two parts, one part specific to the cross-sectional unit or "group" and the other specific to the particular observation. Therefore, in this model, the error term $\left(\varepsilon_{i t}\right)$ represents composite error term (Gujarati, Porter, \& Gunasekar, 2012) :

$$
\begin{array}{lll}
\varepsilon_{i t} & =\left(u_{i}+v_{i t}\right) \\
Y_{i t} & =\alpha+\beta^{\prime} X_{i t}+\left(u_{i}+v_{i t}\right) & (\text { Model 2) }
\end{array}
$$

Where, $u_{i}$, is the cross-specific error component and $v_{i t}$ which is the combined time series and cross-section error component. Based on the generalized models, the regression equation for the study has been specified as: 


$$
\mathrm{ROA}_{\text {it }}=\alpha+\beta_{1} \mathrm{CDR}_{\mathrm{it}}+\beta_{2} \mathrm{IRS}_{\mathrm{it}}+\beta_{3} \mathrm{NPLR}_{\mathrm{it}}+\beta_{4} \mathrm{CAR}_{\mathrm{it}}+\varepsilon_{i t}
$$

Where,

$\mathrm{ROA}_{\mathrm{it}}=$ Return on assets of $i$ th bank for the $t$ th year.

$\mathrm{CDR}_{\mathrm{it}}=$ Credit deposit ratio of $i$ th bank for the $t$ th year.

$\mathrm{IRS}_{\mathrm{it}}=$ Interest rate spread of $i$ th bank for the $t$ th year.

$\mathrm{NPLR}_{\text {it }}=$ Non-performing loan ratio of $i$ th bank for the $t$ th year.

$\mathrm{CAR}_{\mathrm{it}}=$ Capital adequacy ratio of $i$ th bank for the $t$ th year.

$\alpha \quad=$ The intercept of the regression line.

$\beta_{1}, \beta_{2}, \beta_{3}, \beta_{4}$ are regression coefficients.

$\varepsilon_{i t} \quad=$ error component

\section{Variables and Hypotheses}

The variables in this study, as specified in the regression equation, were picked on the basis of the literature relevant to the banking industry. Where, ROA was considered as a dependent variable. On the other hand, credit deposit ratio, interest rate spread, nonperforming loan ratio, and capital adequacy ratio were used as independent variables.

Return on assets (ROA): In this study, ROA had been used as a criterion to assess the consequences of the predictors: credit performance and capital adequacy. Here, the return on assets corresponds to the ratio of the bank net after-tax income divided by its total assets. It is primarily an indicator of managerial efficiency (Rose, 2002).

Credit deposit ratio (CDR): It corresponds to the ratio of total loans to total deposit. It represents as one of the indicators of credit risk of commercial banks and also reflects the banks' liquidity. If the ratio is too high, it means that the bank may not have enough liquidity to cover any unforeseen fund requirements, and conversely, if the ratio is too low, the bank may not be earning as much as it could be. Islam and Nishiyama (2016) found the significant negative consequence of CDR on ROA in their study with dynamic panel evidence from south Asian countries. Hence, with these perspectives, the following hypothesis regarding the CDR had been developed.

$H_{1}$ : Credit deposit ratio has a significant and negative consequence on return on asset.

Interest rate spread (IRS): It represents the difference between the interest rates on deposits and loans. This study had focused to the weighted average interest rate spread. The greater the spread, the more profitable the financial institution is likely to be. Bhatia, Mahajan, and Chander (2012) found the significant positive impact of IRS on ROA. Therefore, the following hypothesis regarding the IRS had been developed.

$\mathrm{H}_{2}$ : Interest rate spread has a significant and positive consequence on return on assets. 
Non-performing loan ratio (NPLR): As one of the predictors, this ratio represents the amount of nonperforming loans in a bank's loan portfolio to the total amount of outstanding loans the bank holds. The literatures consider it as one of the major indicators of the credit risk and credit quality. It measures the effectiveness of a bank in receiving repayments on its loans. Bhatia, Mahajan and Chander (2012) found the significant negative effect of NPLR on ROA in Indian context. Hence, a hypothesis regarding the consequence of NPLR had been developed as:

$H_{3}$ : Non-performing loan ratio has a significant and negative consequence on return on asset.

Capital adequacy ratio (CAR): It measures the bank's capacity to handle the losses and meet all its obligations towards the customers without ceasing its operations. It is calculated by dividing a bank's capital by its risk-weighted assets. The main objective of maintaining the required capital adequacy is to protect depositors and promote the stability and efficiency of financial systems. Hence, it apparently involves the significant cost. Pradhan and Shrestha (2016) found a negative relation between CAR and ROA. Based on these perspectives, the study had developed the fourth hypothesis as follows:

$H_{4}$ : Capital adequacy ratio has a significant and negative consequence on return on asset.

\section{Results and Discussion}

\section{Descriptive Statistics and Correlations}

Table 1 highlights statistics to describe the features of the data set and a statistical measure of the strength of the relationship between the study variables. Hence, it gives a general scenario. As shown in Table 1, it was found high dispersion in NPL $(M=1.22$, $S D=1.21)$. It indicates the much variability of non-performing loan ratio between the commercial banks. In contrast, CDR seems more consistent $(M=83.44, S D=7.95)$ among the banks. Relative to the NPL, other predictors, IRS and CAR seems also consistent. So far the case of ROA, a criterion of this study is concerned, it had a mean of $1.66(S D=0.43)$ and indicates volatility among the banks but less in comparison to NPL. 
Table 1

Descriptive Statistics and Correlations for Study Variables

\begin{tabular}{lrcccccc}
\hline \multicolumn{1}{c}{ Variable } & \multicolumn{1}{c}{$M$} & \multicolumn{1}{c}{$S D$} & 1 & 2 & 3 & 4 & 5 \\
\hline 1. CDR & 83.44 & 7.954 & - & & & & \\
2. IRS & 4.20 & 0.502 & -.192 & - & & & \\
3. NPLR & 1.22 & 1.208 & -.041 & .161 & - & & \\
4. CAR & 13.62 & 2.039 & $-.278^{* *}$ & .079 & $-.250^{*}$ & - & \\
5. ROA & 1.66 & 0.430 & $-.408^{* *}$ & $.216^{*}$ & $-.298^{* *}$ & .193 & - \\
\hline
\end{tabular}

Note. The results were based on the $n=95$, balanced pool from 19 private sector commercial banks.

Results were extracted via SPSS, version 16.0.

$* p<.05 . * * p<.01$.

The coefficients of correlations matrix, as shown in Table 1, is the results of Pearson's correlations, two tailed. Basically, all the correlations coefficients among the independent variables are less than 0.28 , implying the absence of multicollinearity. The results indicated that there was a significant negative association between CDR and ROA, $(r=-.408 ; p<.01)$. Likewise, there was a significant negative association between NPLR and ROA $(r=-0.298, p<.01)$. Whereas, there was a moderate positive correlation between the IRS and ROA $(r=.216, p<.05)$. In contrast, the association between CAR and ROA was weak $(r=.193)$ and the result was statistically not significant.

\section{Regression Results}

Primarily, the model diagnostic test was conducted to choose the appropriate panel regression model from among the pooled OLS, fixed effect, and the random effect model for the data set used in this study. In this process, Pooled OLS model was used as a threshold to move forward. The details of test results are enumerated in Table 2.

The test was started by using Joint significance of differing group means to choose among the pooled OLS model and fixed effect model with the null hypothesis that the pooled OLS model was adequate. Again, in order to compare the pooled OLS model with a random effect model, the Breusch-Pagan test statistic was used with the null hypothesis that the pooled OLS model is adequate. 
Table 2

Model Diagnostic Results

\begin{tabular}{|c|c|c|c|c|}
\hline $\begin{array}{l}\text { Model } \\
\text { comparison }\end{array}$ & Test statistic & $\begin{array}{l}\text { Joint } \\
\text { significance of } \\
\text { differing group } \\
\text { means' test } \\
\text { result }\end{array}$ & $\begin{array}{l}\text { Breusch-Pagan } \\
\text { test result }\end{array}$ & $\begin{array}{l}\text { Hausman test } \\
\text { result }\end{array}$ \\
\hline $\begin{array}{l}\text { Compare } \\
\text { pooled OLS } \\
\text { model with } \\
\text { fixed effect } \\
\text { model }\end{array}$ & $\begin{array}{l}F(18,72)= \\
2.7418 \text { with p- } \\
\text { value } .0013\end{array}$ & $\begin{array}{l}\text { Reject the null } \\
\text { hypothesis that } \\
\text { the pooled OLS } \\
\text { model is } \\
\text { adequate. }\end{array}$ & & \\
\hline $\begin{array}{l}\text { Compare } \\
\text { pooled OLS } \\
\text { model with } \\
\text { random } \\
\text { effect model }\end{array}$ & $\begin{array}{l}\mathrm{LM}= \\
9.1143 \text { with } p- \\
\text { value }=\operatorname{prob}\left(\chi^{2}\right. \\
(1)>9.1143)= \\
.0025\end{array}$ & & $\begin{array}{l}\text { Reject the null } \\
\text { hypothesis that } \\
\text { the pooled OLS } \\
\text { model is } \\
\text { adequate. }\end{array}$ & \\
\hline $\begin{array}{l}\text { Compare } \\
\text { random } \\
\text { effect model } \\
\text { with fixed } \\
\text { effect model }\end{array}$ & $\begin{array}{l}\mathrm{H}=4.5584 \\
\text { with } p \text {-value }= \\
\operatorname{prob}\left(\chi^{2}(4)>\right. \\
4.5584)=.3356\end{array}$ & & & $\begin{array}{l}\text { Fail to reject } \\
\text { the null } \\
\text { hypothesis that } \\
\text { the random } \\
\text { effects model is } \\
\text { consistent. }\end{array}$ \\
\hline
\end{tabular}

Note. Test was carried out by using Gretl, version 1.9.4.

Finally, to confirm the consistent model amongst the fixed effect and random effect, the Hausman test statistic was used in testing the null hypothesis that the random effects model is consistent. Gujarati, Porter, and Gunasekar (2012) highlighted Hausman test as a formal test to choose among fixed effect and random effect estimators for panel data. As noticed by the results of the Hausman test, $\mathrm{H}=4.5584$ with $p$-value $=\operatorname{prob}\left(\chi^{2}(4)>\right.$ $4.5584)=.3356$, it failed to reject the null hypothesis $(p$-value $>.05)$. Therefore, it was concluded to adopt the random effect model to draw the inferences from the data set of this study. However, the results of Pooled OLS were also discussed alongside. 
Table 3

Regression Results Using ROA as the Criterion

\begin{tabular}{|c|c|c|c|c|c|c|c|c|}
\hline \multirow{2}{*}{ Variable } & \multicolumn{4}{|c|}{ Model 1: Pooled OLS } & \multicolumn{4}{|c|}{ Model 2: Random effect GLS } \\
\hline & Coefficient & $S E$ & $t$-ratio & $p$-value & Coefficient & $S E$ & $z$ & $p$-value \\
\hline Constant & 2.903 & 0.681 & 4.261 & $<.001^{* *}$ & 2.258 & 0.696 & 3.244 & $.002^{* *}$ \\
\hline CDR & -0.021 & 0.005 & -4.161 & $<.001^{* *}$ & -0.017 & 0.006 & -2.719 & $.008^{* *}$ \\
\hline IRS & 0.171 & 0.078 & 2.187 & $.031^{*}$ & 0.171 & 0.074 & 2.311 & $.023^{*}$ \\
\hline NPLR & -0.125 & 0.033 & -3.775 & $<.001^{* *}$ & -0.119 & 0.038 & -3.132 & $.002^{* *}$ \\
\hline CAR & -0.004 & 0.020 & -0.196 & .845 & 0.015 & 0.022 & 0.697 & .488 \\
\hline \multicolumn{2}{|c|}{$S E$ of regression } & \multicolumn{3}{|c|}{0.3669} & \multicolumn{2}{|c|}{$S E$ of regression } & \multicolumn{2}{|c|}{0.3676} \\
\hline$R^{2}$ & .303 & \multicolumn{2}{|c|}{ Adj. $R^{2}$} & .272 & \multicolumn{2}{|c|}{ Durbin-Watson } & 1.430 & \\
\hline$F(4,90)$ & 9.758 & \multirow{3}{*}{\multicolumn{2}{|c|}{$P$-value $(F)$}} & $<.001$ & \multirow{3}{*}{\multicolumn{4}{|c|}{$\begin{array}{l}\frac{\text { Wooldridge test for autocorrelation }}{F(1,18)=1.930 ; p \text {-value }=.182} \\
\frac{\text { Test for normality of residual }}{\chi^{2}(2)=0.687 ; p \text {-value }=.709}\end{array}$}} \\
\hline Max. VIF & 1.18 & & & & & & & \\
\hline & & & & & & & & \\
\hline
\end{tabular}

Note. The results were derived from gretl, version 1.9.4.

**. Significant at the .01 level.

*. Significant at the .05 level.

As revealed by Table 3, from the pooled OLS model, it was found that the study predictors (CDR, IRS, NPLR, and CAR) collectively explain a significant amount of variations in the return on assets $\left(F(4,90)=9.758, p<.05, R^{2}=.303, R_{\text {Adjusted }}^{2} .272\right)$. As estimated by the coefficient of determination, $R^{2}$ statistic, it was found as 30.3 percent predictability of variance in the criterion by the model. It could be justifiable because the study was limited to the few proxies of credit performance and capital adequacy as the predictors. In addition, the rational argument was that the model diagnostic had confirmed in favor of random effect GLS. As argued by Adkins (2018), $R^{2}$ is only suitable for linear models estimated using OLS, which is the case for one-way fixed effects. Therefore, gretl has omitted $R^{2}$ for the random effects model. Despite that the almost similar statistic of SE of regression in OLS and GLS verify the reasonable predictability of variance in the criterion by the model. The random effect GLS as a consistent estimator for the data set, hereafter, individual predictors as well as the entire statistic examined accordingly.

As a test of the presence of multicollinearity among predictor variables in the model, the variance inflation factors (VIF) have been calculated. As a result, the maximum VIF was confirmed at 1.18. As indicated by Gujarati, Porter, and Gunasekar (2012), if the VIF of the variable exceeds 10 that variable is said to be highly collinear and problematic. Hence, the predictor variables chosen for the model did not suffer from the multicollinearity problem. Similarly, the test of normality was also conducted. The test 
statistic for normality of residual $\left(\chi^{2}(2)=0.687 ; p=.709\right)$ verified that the underlying residuals are normally distributed. In order to test the autocorrelation, Durbin-Watson statistic and Wooldridge test for autocorrelation had been used. Durbin-Watson statistic 1.430 and Wooldridge test result $(F(1,18)=1.930, p=.182)$ confirmed no problem of autocorrelation. However, the Breusch-Pagan test showed the problem in the variance of the unit-specific error.

As revealed by the coefficient statistic, $\operatorname{CDR}(z=-2.719, p=.008)$ was one of the significant predictors in the model. It showed the coefficient -.017 indicating the consequence of one unit change in CDR on ROA. It indicates that increase in credit deposit ratio leads to decrease the return on assets of the banks. The result as expected is consistent with Islam and Nishiyama (2016) where they found that loan to deposit ratio has significant negative effect on return on assets. However, in the Indian context, Bhatia, Mahajan, and Chander (2012) found CDR could not significantly influence the ROA.

The result of IRS ( $z=2.311, p=.023)$ showed the significant positive consequence on ROA with the coefficient 0.171 indicating the effect of one unit change in interest rate spread on return on assets. It indicates that increase in interest rate spread leads to increase the return on assets of the banks. The result is as expected and somehow consistent with Islam and Nishiyama (2016) however, their results was statistically insignificant. On the other hand, NPLR $(z=-3.132, p=.002)$ was also next significant predictor. It showed the coefficient -.125 indicating the effect of one unit change in nonperforming loan ratio on return on assets. It indicates that increase in non-performing loan ratio leads to decrease the return on assets of the banks. The result was as expected and somehow consistent with Islam and Nishiyama (2016). However, their result was statistically insignificant. So far the effect of CAR is concerned, the coefficient was estimated at 0.015 . It indicates that increase in capital adequacy ratio leads to increase the return on assets of the banks. But, the result was statistically insignificant and contrary to priori expectation. The results imply that the relationships were not strong. This result was inconsistent to Pradhan and Shrestha (2016). 
Table 4

Summary of Regression Results Using ROA as the Criterion

\begin{tabular}{llll}
\hline Predictor Variables & $\begin{array}{l}\text { Expected } \\
\text { relationship }\end{array}$ & $\begin{array}{l}\text { Reported } \\
\text { relationship }\end{array}$ & Significance \\
\hline Credit deposit ratio & Negative & Negative & Sig. at .01 level \\
Interest rate spread & Positive & Positive & Sig. at .05 level \\
Non-performing loan ratio & Negative & Negative & Sig. at .01 level \\
Capital adequacy ratio & Negative & Positive & Not significant \\
\hline
\end{tabular}

\section{Conclusions and Implications}

Using a balanced panel data set with the predictor variables corresponding to the credit performance and capital adequacy ratio of private sector commercial banks in Nepal, this paper presents the empirical results on how those factors affect the bank profitability. Return on assets, a criterion variable, was considered as a proxy of the profitability. The study followed the random effect GLS estimator for the empirical analysis after the model diagnostic that include nineteen commercial banks' data covering the period of 2016-2020. Since the study was limited to the four bank specific predictor variables, the empirical finding regarding the predictability of the model seems rational.

The estimated regression model reveals that credit to deposit ratio has negative and statistically significant impact on the return on assets of private sector commercial banks. As a financial intermediary, the fundamental business of the banking industry is lending. But the result of correlation and regression estimates shows as the unconstructive figure. The average of credit deposit ratio also signifies the fact. Correspondingly, the result of the non-performing loan ratio also seems negative. It is common understanding; however, the size of negative effect and association with return on assets does not give the fine impression and should alert on the issue. The estimate of the consequence of interest rate spread is positive and statistically significant in building the profitability. Apparently, the coefficient of the positive effect size shows encouraging in profit making while the study indicates no statistical evidence about the consequence of capital adequacy ratio in the return on assets. The result estimates the capital adequacy ratio is weak in explaining the variation of profitability. Perhaps, it is due to the mandatory provisions of governing bodies. Eventually, this study concludes that the private sector commercial banks are in the tendency of aggressive lending policy. It is a credit risk matter and raises a question mark in the credit risk management.

Though banking is one of the most heavily regulated businesses in the world, the results of this study, as a policy implication suggest the commercial banks as well as the regulatory authority to alert the credit performance and suggest developing a rational 
credit performance policy that benefits the society as a whole. Moreover, so far the implications to the academia are concerned, this paper has addressed the questions regarding few bank specific variables. However, studies on a number of additional predictor variables could not be tested due to limitation of the study horizon fixed about. In addition, rectifying the problem in the variance of the unit-specific error by implementing contemporary econometric methodology in the model would be fruitful insight in the academia and will be the interesting path for future research.

\section{References}

Bhatia, A., Mahajan, P., \& Chander, S. (2012). Determinants of Profitability of Private Sector Banks in India. Journal of Commerce and Accounting Research , 1 (2), 14-22.

Bhattarai, B. P. (2020). Determinants of Capital Adequacy Ratio of Commercial Banks in Nepal. Asian Journal of Finance \& Accounting , 12 (1), 194-213.

Bhattarai, Y. R. (2016). Effect of Credit Risk on the Performance fo Nepalese Commercial Banks. NRB Economic Review, 28 (1), 41-64.

Budhathoki, P. B., \& Rai, C. K. (2020). The Effect of Specific Factors on Bank Profitability: Evidence from Nepalese Banks. Journal of Economics and Business , 3 (1), 82-89.

Gautam, R. (2018). Determinants of Financial Performance: an Evidence from Nepalese Commercial Banks. Amity Journal of Strategic Management , 1 (2), 7-13.

Gnawali, A. (2018). Non-Performing Asset and its Effects on Profitability of Nepalese Commercial Banks. International Journal of Research in Business Studies and Management , 5 (9), 39-47.

Gujarati, D. N., Porter, D. C., \& Gunasekar, S. (2012). Basic Econometrics (5 ed.). New Delhi: Tata McGraw Hill Education Private Limited.

Islam, S., \& Nishiyama, S.-I. (2016). The Determinants of Bank Profitability: Dynamic Panel Evidence from South Asian Countries. Journal of Applied Finance \& Banking , 6 (3), 77-97.

Mohanty, S., \& Mahakud, J. (2019). Dynamic Adjustment Towards Target Capital Adequacy Ratio: Evidece from Indian Commercial Banks. Global Business Review , 20 (3), 757-768.

Neupane, B. P. (2020). Profitability Determinants of Nepalese Commercial Banks. PressAcademia Procedia , 12, 40-45.

Poudel, S. R. (2018). Impact of credit risk on profitability of commericial banks in Nepal. Journal of Aplied and Advanced Research , 3 (6), 161-170. 
Pradhan, R. S., \& Shrestha, A. K. (2016). The Impact of Capital Adequacy and Bank Operating Efficiency on Financial Performance of Nepalese Commericial Banks. Nepalese Journal of Management , 3 (3), 1-11.

Ranabhat, D. (2019). Effects of Internal Factors on Financial Performance of Joint Venture Banks in Nepal. The Journal of Nepalese Business Studies , XII (1), 8799.

Risal, H. G., \& Poudel, S. (2020). Role of Credit Risk in Performance difference between A and B Class Banks in Nepal. NRB Economic Review , 32 (1).

Rose, P. (2002). Commercial Bank Management (5 ed.). USA: Mc Graw-Hill/Irwin. 